\title{
ARCHEOLOGIA POLSKI
}





\section{ARCHEOLOGIA POLSKI}

TOM LXV

2020

@

WARSZAWA 
To m rece n z o w a n y

S k ł a d R e d a k c j i N a u k o w e j:

Redaktor: MARIA DEKÓWNA

Z-ca Redaktora: TOMASZ PUROWSKI

Sekretarz: JOLANTA SADOWSKA-TOPÓR

Członkowie Redakcji: ROMUALD SCHILD, HANNA KOWALEWSKA-MARSZAŁEK

S k ła d Ko m i t e t u R e d a k c y j n e go:

JOSEF BÁTORA (Bratysława), FELIX BIERMANN (Szczecin),

JOHAN CALLMER (Lund), HANNA KÓČKA-KRENZ (Poznań),

SARUNAS MILISAUSKAS (Buffalo), MARIAN RĘBKOWSKI (Szczecin/Warszawa),

DANICA STAŠŠÍKOVÁ-ŠTUKOVSKÁ (Nitra), EKATERINA STOLYAROVA (Moskwa), NATALIE VENCLOVÁ (Praga)

A d r e s R e d a k c j i:

Instytut Archeologii i Etnologii PAN

00-140 Warszawa, al. Solidarności 105

tel. (0-22) 6202881 do 84 wewn. 138, 171

e-mail: archeologia.polski@wp.pl

K o r e k ta:

Dorota Cyngot

PL ISSN 0003-8180

(C) Copyright by Instytut Archeologii i Etnologii PAN

Warszawa 2020

No part of this publication may be reproduced or transmitted in any form or by any means, electronic or mechanical, including photocopy, recording, or any information storage and retrieval system, without permission from the copyright owner.

Publikacja tomu współfinansowana przez Ministerstwo Nauki i Szkolnictwa Wyższego w ramach programu

„Wsparcie dla czasopism naukowych” (Umowa Nr 64/WCN/2019/1)

\author{
D T P: \\ Janusz Świnarski \\ D r u k: \\ ???
}

Nakład 260 egz., objętość 26,5 ark. wydawn., papier offset 90 g

Druk ukończono w grudniu $2020 \mathrm{r}$. 


\section{SPIS TREŚCI}

\section{METODY I METODOLOGIA}

A n d r zej M i e r z w i ń ski, Paleokrajobrazowe aspekty badań nad podepozycyjnymi procesami destrukcji ceramiki osadowej (przypadek kunicki) / Paleo-landscape aspects of research on post-depositional processes of destruction of settlement cera-

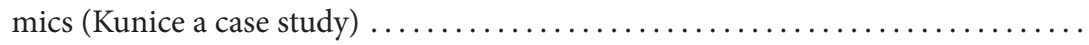

\section{STUDIA}

Sylwe st e r C z o p e k, Znaczenie odkryć w Chotyńcu (południowo-wschodnia Polska) dla interpretacji procesów kulturowo-historycznych na zachodnim Wołyniu i Podolu (Ukraina) we wczesnej epoce żelaza / The significance of discoveries from Chotyniec (south-eastern Poland) for the interpretation of cultural and historical processes in western Volhynia and Podolia (Ukraine) in the Early Iron Age

$\mathrm{S}$ u e $\mathrm{H}$ e a s e r, Dark ellipsoid beads with opaque glass thread decoration found in Britain

Władysław D u c z k o, Skandynawowie nad rzeką Parsętą: problem wikińskich grobów na cmentarzysku w Świelubiu na Pomorzu Zachodnim / Scandinavians on the banks of the Parsęta river: Viking graves in the cemetery at Świelubie in Western Pomerania

Ka r o l Kollinger, Prolegomena do studiów nad gramotami brzozowymi / Prolegomena to the study of birchbark manuscripts

Danica Staśšíková-Štukovská, Dagmar Galusková, Alfonz $\mathrm{Pl}$ š k o, Glass melting experiments in the reconstruction of glass furnace from the $9^{\text {th }}$ century

Mag d a l e n a B i s, Zarys stanu i problematyki polskich badań nad naczyniami szklanymi z XIV-XVIII wieku w latach 1987-2018 / A summary of the state of the Polish research into glass vessels from the $14^{\text {th }}-18^{\text {th }}$ centuries carried out in the years 1987-2018 and the outline of key research problems

\section{DYSKUSJE I POLEMIKI}

Ha l i n a D o b r z a ń s ka, W kwestii uwarunkowań środowiskowych wytwórczości ceramiki „ścieralnej” w kulturze przeworskiej / Natural environment factors conditioning the production of "abradable" pottery in Przeworsk culture 


\section{RECENZJE}

Iwona Sobkowiak-Tabaka, Rozwój społeczności Federmesser na Nizinie Środkowoeuropejskiej (Katarzyna Kerneder-Gubała)

„Archeologia Polski” jest indeksowana w bazach: Scopus, CEJSH (The Central European Journal of Social Sciences and Humanities) i Index Copernicus Journals Master List "Archeologia Polski” is indexed in: Scopus, CEJSH (The Central European Journal of Social Sciences and Humanities), and Index Copernicus Journals Master List 


\title{
OD REDAKCJI
}

„Archeologia Polski” jest wydawnictwem ciągłym, w którym zamieszczane są artykuły zawierające ujęcia ogólne, syntetyzujące, omawianych zagadnień. Publikujemy w nim prace z zakresu metodologii i metodyki badań archeologicznych oraz dyscyplin współpracujących $\mathrm{z}$ archeologią, a także studia dotyczące problematyki prehistorii oraz wczesnych dziejów ziem polskich na tle europejskim. Każdy zeszyt zawiera również dział polemik i dyskusji oraz recenzje literatury polskiej i obcej, głównie archeologicznej, lecz również prac z zakresu dyscyplin z archeologią współpracujących.

Artykuły i recenzje przekazywane do druku w „Archeologii Polski” prosimy opracowywać według zasad opublikowanych w tomie 61: 2016, s. $279 \mathrm{nn}$. naszego periodyku, oraz na stronie internetowej: www.iaepan.edu.pl.

Warunki zamawiania „Archeologii Polski”

Instytucje i osoby prawne mogą kierować zamówienia na adres:

\author{
Instytut Archeologii i Etnologii PAN; al. Solidarności 105, 00-140 Warszawa, \\ numer konta w BANK BGK 58113010170020146597200001 \\ z dopiskiem „Archeologia Polski” \\ Zachęcamy do składania zamówień w naszej księgarni internetowej na stronie: \\ www.iaepan.edu.pl \\ tel. (+ 48 22) $6202881 \div 86$, w. 114, (+ 48 22) 652 1959; bookshop@iaepan.edu.pl
}

Po otrzymaniu zamówienia prześlemy tom wraz z rachunkiem (cena numeru plus opłata przesyłki). Bieżące i wcześniejsze numery można nabyć lub zamówić (przesyłka za zaliczeniem pocztowym) w Księgarni IAE PAN, al. Solidarności 105, 00-140 Warszawa, bookshop@iaepan.edu.pl

Subscriptions orders for "Archeologia Polski" available directly from Institute of Archaeology and Ethnology

al. Solidarności 105, 00-140 Warszawa, Poland

The subscription rate is EURO 44 \& postage. Payment should be made by credit card,

by International Money Order sent to

BANK BGK 58113010170020146597200001

or by a check made payable to Instytut Archeologii i Etnologii PAN;

al. Solidarności 105, 00-140 Warszawa, Poland

We recommend using an order form available in the Institute's bookshop on our website:

www.iaepan.edu.pl 


\section{For the exchange write, please, to}

Instytut Archeologii i Etnologii PAN - Biblioteka

al. Solidarności 105, PL 00-140 Warszawa, Poland tel. (+48 22) $6202881 \div 86$ int. 175

Orders regarding all publications of the Institute of Archaeology and Ethnology should be addressed to the Institute of Archaeology and Ethnology, Polish Academy of Sciences, al. Solidarności 105, PL-00-140 Warszawa, Poland, tel. + $48226202881 \div 86$ int. 114, fax + 48226240100 (Warsaw).

We recommend using an order from available in the Institute's bookshop on our website:

$$
\text { www.archaeology.pl }
$$

or

$$
\text { bookshop@iaepan.edu.pl }
$$

Payment must be made by International Money Order sent to BANK BGK No 58113010170020146597200001 or by check payable to Instytut Archeologii i Etnologii PAN, al. Solidarności 105, PL-00140 Warszawa, Poland 